\author{
Krzysztof Jarzęcki \\ https://doi.org/10.26485/AAL/2021/67/7
}

\title{
ANCIENT COINS IN THE COLLECTION OF THE JAN KASPROWICZ MUSEUM IN INOWROCEAW
}

\begin{abstract}
The article concerns 23 ancient coins (8 Greek, 1 Numidian, and 14 Roman) from the museum collection in Inowrocław. One coin comes from archaeological excavations (a Trajanic denarius type RIC 6), the rest from donations and purchases. The coins donated to the museum are chance finds, however the donors indicated the place where they were found. The remaining coins have been purchased from old collections. In one case their previous owner is known: Kazimierz Miaskowski (1875-1947), a catholic priest, and author of many publications associated with the Inowrocław region. The land around Inowrocław stands out as an area in which many ancient coins have been found. The author analyses coins from the museum against the background of finds from the Inowrocław area. Many of the coins in the collection are likely to have been found in the immediate area of the town. The author also tries to reconstruct the collections from which they came, and the fate of these collections.
\end{abstract}

Keywords: ancient coins, Greek coins, Numidian coins, Roman coins, Cuiavia, coin finds, Przeworsk culture, museum collection, Kazimierz Miaskowski (1875-1947)

\section{MONETY ANTYCZNE W ZBIORACH MUZEUM IM. JANA KASPROWICZA W INOWROCŁAWIU}

\begin{abstract}
ABSTRAKT Artykuł dotyczy 23 monet antycznych z kolekcji muzealnej (8 greckich, 1 numidyjska i 14 rzymskich). Jedna moneta pochodzi z wykopalisk archeologicznych (denar Trajana typu RIC 6), pozostałe z darów i zakupów. Monety przekazane do muzeum to przypadkowe znaleziska. Ofiarodawcy wskazali jednak miejsce ich znalezienia. Pozostałe to zakupy, które pochodzą z dawnych kolekcji. W jednym przypadku znany jest ich poprzedni właściciel - ks. Kazimierz Miaskowski (1875-1947), autor wielu publikacji związany z okolicą Inowrocławia. Okolica Inowrocławia wyróżnia się jako miejsce znajdowania wielu monet antycznych. Autor analizuje monety z muzeum na tle znalezisk z okolic Inowrocławia. Bardzo prawdopodobne, że wiele monet pochodzących z kolekcji jest znaleziskami z najbliższej okolicy. Autor podejmuje też próbę rekonstrukcji kolekcji z których pochodziły i ich losów.
\end{abstract}

Słowa kluczowe: monety antyczne, monety greckie, moneta numidyjska, monety rzymskie, Kujawy, znaleziska monet, kultura przeworska, kolekcja muzealna, Kazimierz Miaskowski (1875-1947)

Ancient coins that are found in Poland are found in several distinct clusters. One of them is Cuiavia, ${ }^{1}$ especially the western part of the region near Inowrocław. The fate of the oldest finds, usually made by chance, varied. Coins were melted

1 It is worth adding that the concentration of finds of ancient coins from the vicinity of Inowrocław was recognized as one of the first in Poland, Zakrzewski 1938: 66. On the increase in knowledge about finds during the 20th century, see Jarzęcki, Rakoczy 2010: 28-29. down, ${ }^{2}$ turned into other objects, ${ }^{3}$ or ended up in the collections of private persons and institutions. ${ }^{4}$ Finds made after World War II were slightly more 'lucky'. Some of them were made in the course of

2 Mielczarek 1989: 139.

3 See the Trajanic denarius discovered in a modern grave in Inowrocław, cat. no. 13.

4 Mielczarek 1989: 139-140; Jarzęcki, Rakoczy 2010: 55-61. The most famous private collections containing finds of ancient coins from Inowrocław and the surrounding area belonged to Fr. Antoni Laubitz and Dr. Michael Levy. Both are known only from references in the literature. 
archaeological excavations, so they were usually recorded in the relevant literature. The nature of these publications, however, depended on the individual interests of the discoverers. Thus, these include both detailed studies, and mere mentions of little scientific value. The coins found in this way, were scattered among various archaeological research centres. Chance finds have also been made by private persons by means of metal detectors. These coins, although in the light of Polish law are the property of the State Treasury, remain in private collections, or are sold. Many attempts have been made to publish them without information about the exact context (e.g. more precise than a specific place) and the finder. ${ }^{5}$ The advantage of such publications is they attempt to introduce these finds, which are not directly accessible to researchers, into the scientific discussion, while the disadvantage is the lack of any possibility of their verification. In the light of these circumstances, the paradox of the collection of ancient coins from Inowrocław under discussion is understandable. Namely that despite the exceptional "potential" of the Inowrocław area which abounds in coin finds, the museum collection comprises less than thirty specimens. At the same time, it is obvious that the collection demands special treatment, given that it consists not only of coins bought from the trade, but evidently also of finds definitely, or very likely, coming from the immediate area. The purpose of this article is to investigate and publish the collection of ancient coins in the collection of the Jan Kasprowicz in Inowrocław (Poland). It is the first publication of this collection as a whole. In the case of the few coins that have already been published, this article seeks to supplement and correct false or outdated information in light of the current state of research. ${ }^{6}$

E.g. Dymowski, Rudnicki 2012; Rudnicki, Dymowski 2015; Dymowski; 2017, cf. Bodzek, MadydaLegutko 2018: 72

${ }^{6}$ I would like to thank the employees of The Jan Kasprowicz Museum in Inowrocław, and especially Mr. Marcin Woźniak and Sebastian Jarecki, who provided access to the coins and documentation. I could rely on their interest in my research and their help whenever I needed it. I would like to sincerely thank professor Jarosław Bodzek for his valuable suggestions regarding Bithynian coins. The comments of Jerzy Piniński about coins allegedly found in Lake Piłakno were also very useful. I am very grateful to him. I also used the kind help of professor Małgorzata Grupa for which I would like to thank her.
The numismatic collection, which is the subject of this article, begins with the collection of the Regional Museum of West Cuiavia, established in 1931, which, reactivated after the war, since 1966 has been called the Jan Kasprowicz Museum. Before the war, the collection of this museum included three ancient coins:

1. denarius of Vespasian, found in Modliborzyce (commune of Dąbrowa Biskupia), obtained in 1936;

2. denarius of Antoninus Pius, found in Gąski (commune of Gniewkowo), gift from Antoni Kaźmierczak from Gąski, donated in 1936;

3. denarius of Trajan, found in Kłobia (commune of Lubraniec), gift from Antoni Kaźmierczak from Gąski, handed over by Zygmunt Zakrzewski in $1936 .^{7}$

The coins were defined by Zygmunt Zakrzewski (1867-1951), one of the greatest Polish authorities in the field of numismatics at the time. ${ }^{8}$ During World War II, the numismatic collection of the museum, numbering more than 300 items, was stolen or dispersed by the Germans. The current collection, which includes over 10,000 items, was entirely created after the museum's reopening in 1959 from donations, purchases, and archaeological research conducted by the museum. This article is the first systematic publication of a portion of this little-known collection that includes ancient coins.

Only one of the described coins was discovered during archaeological research. It is a Trajanic denarius (cat. No. 13) discovered in a modern grave in Inowrocław in 2010. The uniqueness of the find is due not only to the fact that this coin was found in a grave dating to the 16th-17th century, but also because it served as a medal found on the chest of a deceased woman. A hole was drilled in the coin in such a way as to show the portrait of the emperor, and the reverse was intentionally wiped out. The discovery quickly became known and has already been published several times. Nevertheless, the description of the coin presented in them can be significantly supplemented, and an alternative interpretation of this find will be presented.

The next three coins were transferred to the museum as accidental finds, and the donors indicated the place where they were found. This category includes a denarius of Antoninus Pius (cat. No. 15) found in 1962 in Krusza Zamkowa. The findspot, as we read in a note in the museum's

7 Woźniak 2012: 243.

8 More about Zygmunt Zakrzewski: Politowski 2015. 
archives, was a small hill within the property of citizen Julian Pater; $3 \mathrm{~m}$ from the border of Józef Kowalczyk's estate; near Noteć. A spindle and a fragment of a clay vessel were found near the coin. The description is accompanied by a situational sketch (Fig. 1). The discovery attracted the attention of archaeologists, and, from the beginning of the 1970s, archaeological research was carried out at the site for several dozen years. As a result, Krusza Zamkowa has become one of the most famous archaeological sites in Poland. Based on the research results, the concept of the existence of a local group of the Przeworsk culture was created, and Krusza Zamkowa became its eponymous site. According to Polish terminology, it is the so-called grupa kruszańska. Attempts were also made to identify the settlement thus discovered with Askaukalis, mentioned by Claudius Ptolemy. ${ }^{9}$ However, this last point turned out to be highly debatable. ${ }^{10}$ The only information in the literature regarding the find records the fact that it dates from the times of Antoninus Pius ${ }^{11}$ and an unsigned photo of the obverse among the denarii found in Gąski, which falsely suggests that it was found there as well. ${ }^{12}$ This category of finds also includes a Numidian coin of Masinissa (cat. No. 9). The coin was donated in 1989 by Marian Walczak, an inhabitant of Inowrocław. The donor indicated the exact place where it was found in Inowrocław, on Plac Klasztorny, at the southwest wall of the City Theater. It seems possible that it was found on a secondary deposit, where was brought in 1976 with soil from Rąbin, a district in the southern part of Inowrocław, where a settlement microregion with a concentration of finds of Greek, Celtic, and Roman republican coins has been identified. ${ }^{13}$ The group of finds of which the findspot is approximately known, also includes a bronze coin of the Bithynian city of Nicaea bearing the portrait of Alexander Severus, donated in March 2021 (cat. No. 7). According to the donor, the coin was found in Piłakno lake (Mrągowo district, Sorkwity commune) at a depth of 8 meters. In my opinion, its state of preservation does not indicate that this coin had been underwater for a long time. The photo in the catalog, with its legendary

9 Cofta-Broniewska 1978: 111; 1979: 147; CoftaBroniewska, Kośko 2002: 145.

10 Baranowski, Wielowiejski 1981: 167; Stawicki 2015.

11 Cofta-Broniewska 1979, no. 849.

12 Cofta-Broniewska, Kośko 2002: 163.

13 Kozłowski 2003; Cofta-Broniewska, Bednarczyk 1998: 99.

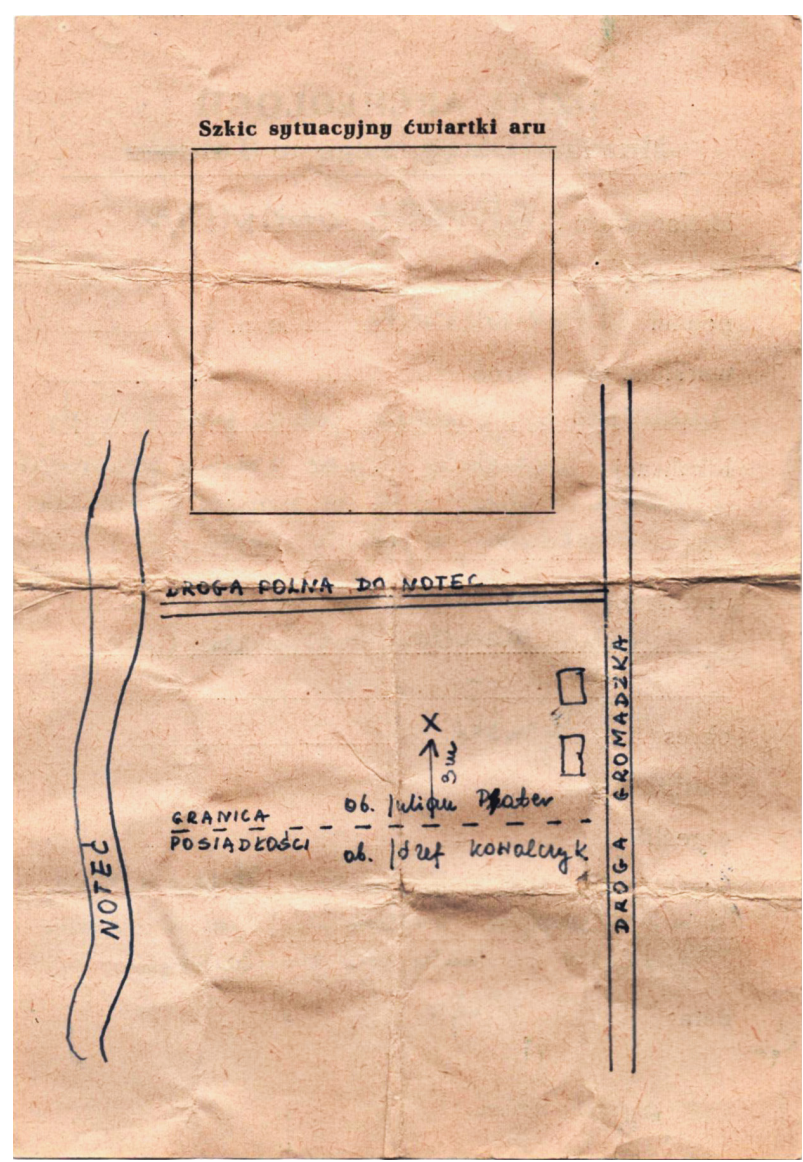

Fig. 1

beautiful cabinet patina, shows the coin in the condition in which it was given to the museum. It should be added that along with the Bithynian coin, a few later coins (including the Prague groschen), covered with a characteristic black coating that couldn't have arisen in an aquatic environment, were also donated to the museum. Many doubts arise in the case of this coin, such as what kind of conservation treatment has it been subjected to, is it a coin that has been left behind in some specific condition, or was it only briefly in the water for some reason, perhaps that it is an attempt to legalize the coin by adding it to other finds, etc. At the present stage, they still remain unanswered. If, however, bearing in mind the above doubts, we take Pitakno Lake or the surrounding area to be the findspot, then it seems to fit well with the map of other Bithynian coins found in this part of Europe, especially if we consider the short distance away it is from in Stare Kiejkuty (Szczytno Commune), where a coin from Prusa struck during the reign of Alexander Severus was found. ${ }^{14}$ Various

14 Myzygin, Sidarovich 2020: 193, 196; Bodzek, Jellonek, Zając 2019: 62; Bursche 1996: 182. 
proposals have been expounded for explaining the circumstances, chronology and routes of entry of the coins of Nicea, and Bithynia in general, in the Central European Barbaricum are to be found in relevant literature, but due to the still small number of such finds, no satisfactory answers have been given. ${ }^{15}$

The most numerous category of the ancient coins under discussion are those which have been purchased from private individuals. The oldest and most numerous purchase was made on 22 June 1965. The purchase comprised 11 coins, packed in paper envelopes. They were Greek and Roman coins from the period of the Republic and Empire (cat. nos. 1, 2, 3, 6, 8, 10, 12, 16, 18, 19, 21). It is not known whether the coins were selected from a larger collection either by the seller or by a museum employee. Perhaps the latter possibility is more likely. After all, it was the first post-war purchase of ancient coins for the museum, which could be treated as the nucleus of a collection including both Greek and Roman coins, and a desired addition to the medieval and modern coins already owned by the museum. Such a decision would have been a good compromise between a limited budget, and the will to expand the museum's collection. In the absence of other ancient coins, it would have been more rational than buying a single, more expensive coin. From an archaeological point of view, it is a collection that could not have been created unconsciously, as a reflection of human activity in any region of the ancient world. It is undoubtedly a collection which was created intentionally, aiming to illustrate the coinage of the ancient world. One of the questions that arises is the influx of these coins into the previous collection. Considering their state of preservation, they can be divided into two groups: coins in very good condition (cat. no. 8, 21) and those bearing very clear traces of their having been circulation, that is, all the rest. Theoretically, such a division could reflect the origin of the coins from the antiquarian trade, and from finds acquired, for example, from discoverers known to the collector of course, for smaller amounts than those bought in an antiquities shop. In favor of such an explanation, apart from the condition of coins No. 8 and 21 , this is also indicated by the envelopes in which they were purchased. They are made of different paper, contain pencil descriptions in Polish, but these are not references to any numismatic literature. The obverse legend of coin no. 8 was read as:

15 Myzygin, Sidarovich 2020: 204.
$\Lambda$ EKAN $\triangle \mathrm{POC}$ CEB[A $\Sigma T O C]$. The reverse of this coin was described as: 'An allegorical figure of Justice standing with scales in his right hand and a rudder (?) in his left. In the field to the left LA' („Alegoryczna postać Sprawiedliwości stojąca Z wagą w prawej ręce i sterem (?) w lewej. W polu na lewo LA"). According to this description, it could have been a coin of Alexander Severus ('Marcus Aurelius Severus AL[EXANDRIA] 222235 ?'). Both the descriptions and the presumed attribution are incorrect. There is no reference to any numismatic literature, although the way of marking the reverse with a characteristic sign resembling the letter $\mathrm{R}$ with a crossed leg is drawn from numismatic literature. The errors can be explained by ignorance of Alexandrian coins and the inability to recognize Roman emperors from their faces, and most of all, from lack of access to any catalogue in which such a coin would have appeared. The same lack of experience in working with ancient coins is also visible in the case of coin No. 19 - a denarius of Marcus Aurelius, which was identified as a denarius of Antoninus Pius. Yet they are quite popular coins, and the portraits of the emperors are made carefully enough to allow for a faultless identification of the coin. The person who had made the identification was probably misled by the fragment of the legend visible [...] NINVS AVG [...]. This either proves that ancient coins were on the margins of the numismatic interests of the owner of the collection, who could have obtained them accidentally as finds or gifts (although he must have had some knowledge of numismatics since he kept the coins in envelopes and had access to other numismatic literature) or, which seems much less likely, the owner of the collection was just beginning his adventure with numismatics and he was creating a collection from relatively inexpensive ancient coins. The accidentality may also be evident in the selection of literature he did use. Apart from Buračkov's 'professional' work, these are all catalogues. On the other hand, there are no references to the works of E. Babelon ${ }^{16}$ and H. Cohen, which were very popular and appreciated at the time. ${ }^{17}$ These are probably the latest specimens in the collection to have been acquired. The remaining coins are less well preserved. They were bought in envelopes made of darker paper, written on in black ink by a nibbed writing implement, which was not a fountain pen. There is one coin in each envelope, except

16 Babelon 1885.

17 Cohen 1859-1868. 
the coins of Olbia Pontica, No. 2 and 3, which were placed in the same envelope with the description 'Graecia - Sarmatia / Olbia'. The descriptions of the coins are in German, e.g. the reverse of the coin No. 12 as: „Mann in Toga zwischen Adler u. Fasces" (Fig. 2) and, in the case of coin number 6, in 'pre-revolutionary' Russian: 'Агриппія [...] Rs. По средине монеты предняя часть корабля (rostra), ободокъ из точекъ. Остался конецъ ндписи ПE $\Omega$ ' (Fig. 3). Below the description of coin number 6 cited above, there is also a reference to Buračkov's work. As a result, it can be suspected that the numbers written on other envelopes (Fig. 4) are encoded references to some sort of literature, e.g. to auction catalogues. The adoption of such a system made it possible to describe each coin only using a small amount of space on the envelope. The language of the descriptions reflects the literature which this person used and at the time, languages which were so well-known to the person describing the coins, that he did not feel the need to translate them into his mother language. In cases where this man did not have access to the appropriate literature, he described the coins in his own native language, Polish, but in pencil. This meant that it would have been a temporary, working description, which after getting access to appropriate literature, would have been replaced with a description written in ink. The envelopes also bear later descriptions written in blue ink with a fountain pen. These are notes written by a museum employee in 1965, with the purchase price, and a set of numbers written in pencil in the upper left corner, probably relating to the cataloguing of these acquisitions into the museum's holdings. In addition, on the reverse of the envelope of coin no. 1 there is an inscription in pencil ' $1 \mathrm{zl}$ ', and on the reverse of the envelope of coin no. 21 ' 2.50 ', which are probably the purchase prices. They probably refer to Polish currency and prices from the period from 1924 to 1939 . No other coins in the Jan Kasprowicz Museum in Inowrocław have similar envelopes. The hypothesis that the previous, pre-museum collection could have received these coins from two sources: from the numismatic market, and from local people who found coins in Cuiavia, seems quite probable. For example, another discovery of a coin of Olbia is known from Rydlewo near Żnin, ${ }^{18}$ and Roman coins of the same

18 Mielczarek 1989: 146. There are known finds of Bosporan coins from Poland. The planigraphy of finds of Greek coins of the northern Pontic poleis in Poland and the interior of Ukraine (eg Mielczarek 2015) indicates

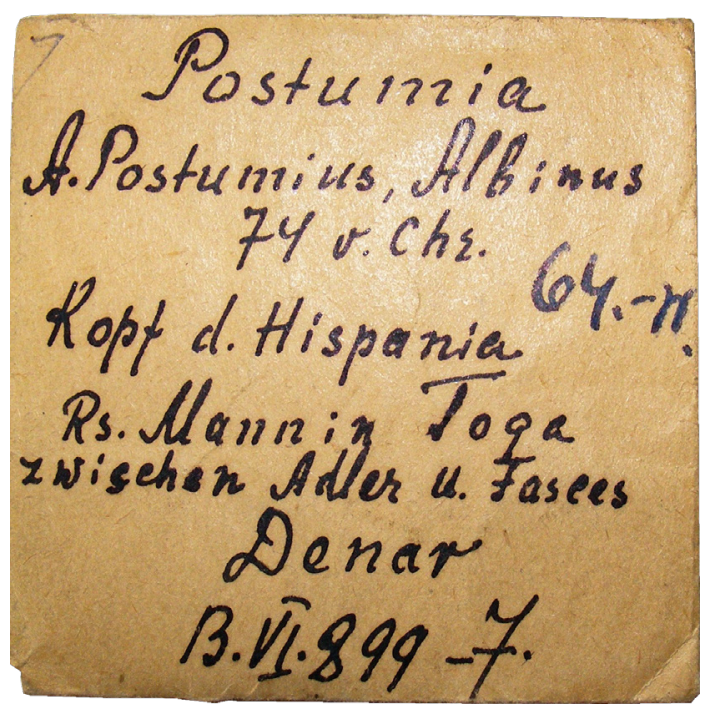

Fig. 2

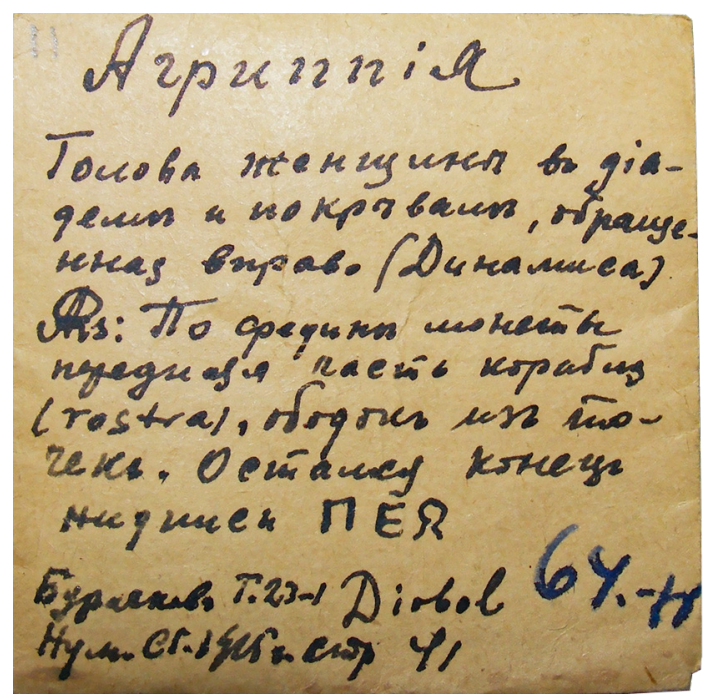

Fig. 3

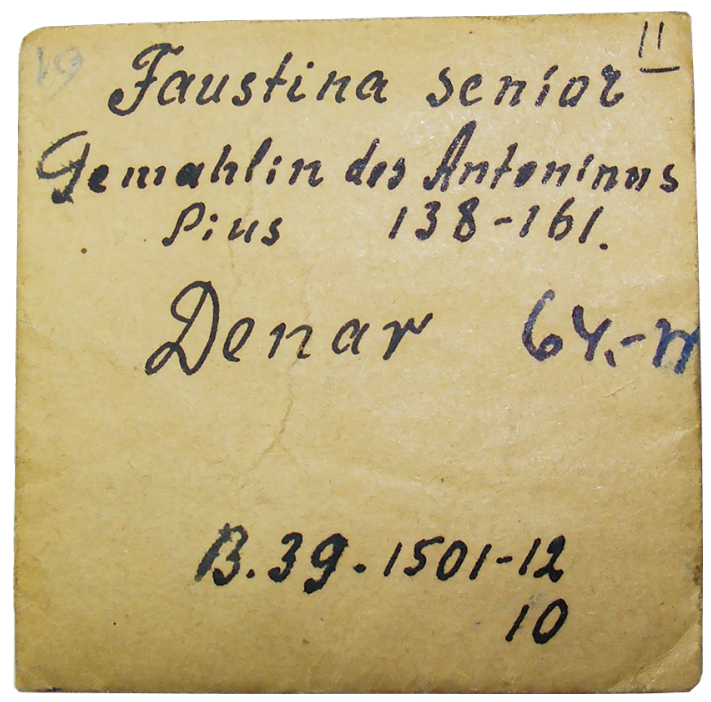

Fig. 4 
issuers are among the most common in Poland. Of course, Cuiavia seems to be the most likely, but not the only findspot for these coins. In the case of Greek coins, apart from the Alexandrian coin, their origin from the northern shore of the Black Sea is clear. Apart from the possibility that they were found in Poland, there exists a possibility that they were brought from the Black Sea region, probably before the First World War. There were many collections formed in this way in Poland. It is enough to recall those known from two volumes of Sylloge Nummorum Graecorum from Warsaw. ${ }^{19}$ Finally, there is a possibility that the Pontic coins were purchased for the museum in Inowrocław as the cheapest among a larger number of Greek coins offered it. Even if this was the case, it does not in any way interfere with the considerations about how the coins got to Cujavia stated above. It is not known who owned the collection, a part of which was purchased by the museum in 1965, and where he lived. Starting this search with inhabitants of Inowrocław and the surrounding area, the most obvious person seems to be the industrialist, Michat Levy (1807-1879). He had a large and famous collection of coins and medals, which also included chance finds. ${ }^{20}$ Levy reportedly donated his

the existence of a route connecting Cuiavia with the Black Sea coast.

19 Walczak 2017; 2018.

20 Jarzęcki, Rakoczy 2010: 56-57; Garbaczewski 2012. In his collection, Levy also had other archaeological artefacts, e.g. Lubomirski 1873: 26-27. In the Jan Kasprowicz Museum, there is a catalogue of the numismatic collection in the form of a manuscript - ,Verzeichnis der Münzsammlung von Michael Levy in Inowroclaw" (the second one is in the collection of the National Museum in Poznań). This included a description of 4 Roman coins, but none of which correspond to the coins currently in the museum. The criterion for selecting the coins presented in the catalogue is their relationship with Polish territory. In the case of the Roman coins, these are references to the Sarmatians (cf. Mielczarek 2021: 37), eg. denarius of Marcus Aurelius with the legend ' $M$ ANTONINVS AVG GERM SARM', and on the reverse, winged Victoria (,geflgelte Victoria”) with the legend 'TR P XXI MP VIII COS III P P'. The collection included, among others, a denarius with the legend of MISICO, according to the author of the catalogue and knowledge at the time, attributed to Prince Mieszko I, a bracteate of Jaxa of Kopenick, coins of Mieszko III the Old described as 'Brakteatae from excavation in the village of Giębolcie (?)', the coronation medal of Michał Korybut Wiśniowiecki and a 'Bronze medal in memory of the fallen in Warsaw 1861'. It is known from other sources that M. Levy had also other ancient coins not mentioned in this catalog, Jarzęcki, Rakoczy 2010: 56-57. collection to the Polish Academy of Arts and Sciences ${ }^{21}$ however, a query addressed to employees of the Jan Kasprowicz Museum did not confirm this. When looking for the owners of these coins, one should also consider lovers of ancient culture, however, not being sure whether they were interested in numismatics at all. One of such people is Władysław Demski (1884-1940), a Catholic priest, vicar in the parish of the Annunciation of the Blessed Virgin in Inowrocław ${ }^{22}$ and a teacher of Latin, Greek and classical culture in local secondary schools. ${ }^{23}$ Another could have been Baroness Helena von Schlichting (1862-1945), the owner of the estate in Wierzbiczany, who, together with her husband and children, went on monthslong expeditions through the countries of southern Europe and northern Africa, especially looking for traces of ancient culture there. ${ }^{24}$ Such traces in the form of coins were also found on her estate, which

21 Laszkiewicz 1997: 29.

22 In the same parish worked before Fr. Antoni Laubitz (1861-1939), a later bishop, a well-known enthusiast of archeology and owner of a coin collection including finds from Inowrocław and the surrounding area. In 1894, he became the vicar of the only parish in Inowrocław, under the invocation of St. Nicholas. In the years 1898-1923 he was the parish priest of the Annunciation of the Blessed Virgin Mary parish. Information about the collection of A. Laubitz, given in the work by Jarzęcki, Rakoczy 2010: 55, 59, 60, refers to the year 1917. Information about finds of coins from Gnojno and Strzemkowo, villages belonging to this parish, are an example of A. Laubitz's collecting activity in 'his area'. It is possible that the discovery of the Nerva denarius made in a garden in the suburbs of Inowrocław (ibid. 56) should be located on the then northern outskirts of the city, on the slope of the hill near the road to Gnojno and Strzemkowo (in the vicinity of the present Marcinkowski and Libelt streets). Looking at the area north of Inowrocław from the perspective of finds of ancient coins and other objects dated to the first centuries of our era, their location on small hills is evident. Most probably, these were settlements. Currently, this area has been highly transformed, but it can be assumed that in Gnojno the settlement was located in the vicinity of some apartment blocks and the fire station. In Strzemkowo it could be the vicinity of the chapel of St. Anthony of Padua, and the manor house in Wierzchosławice. In Sławęcinek, coins have been found on the military training ground (Zakrzewski 1938: 64). An archaeological find that seems to fit in well with this hypothesis is a tomb containing a skeleton surrounded by stones, discovered in 2020 at the top of a hill overlooking a flat area in the north-eastern part of Orłowo.

23 Łaszkiewicz 2010: 14-15.

24 Łaszkiewicz 2014: 111-112. 
included archaeological sites from the Roman period, Gąski and Ostrowo, which had already been identified and described in the literature of that time. ${ }^{25} \mathrm{~A}$ famous expert on the ancient world was Ulrich von Wilamowitz-Moellendorf(1848-1931), classical philologist, lecturer at the University of Göttingen, husband of Marie Mommsen, who was the daughter of Theodor Mommsen. His family property, in which he was born and buried, is Markowice. These are just a few of the more famous examples. No other coins, medieval or modern, were purchased at the same time as the ones described.

Another group of ancient coins (cat. No. 11, $14,17,20)$ was purchased from the former collection of Kazimierz Miaskowski (1875-1947). He is a well-known figure - a Catholic priest, member of the Poznan Society of Friends of the Sciences, and the author of a number of publications in the field of history and librarianship. Ten of his books in Polish and German are listed in the catalogue of the National Library in Warsaw. Coins from the collection of $\mathrm{K}$. Miaskowski are distinguished by significant wear. These issues are quite popular in Poland. This suggests that they may have been found near Miaskowski's place of residence. It is known that he was the parish priest in Ostrów near Pakość (1904-1909) and Ostrów near Gniewkowo (1909-1939). ${ }^{26}$ During World War II and the German occupation, as a Pole, he was forced to go to the territory of the General Government, and after the war until his death he spent his time in Inowrocław. ${ }^{27}$ It can be expected that he knew the coins found in the vicinity of Inowrocław, which ended up with the Poznan Society of Friends of Learning. It is known that the number of recorded finds of coins in a given area depends not only on their actual occurrence, but also on many other factors, including the activity of individual people. A very famous example in Poland is Anatol Gupieniec, operating near Brest-Litovsk (now in Belarus), ${ }^{28}$ and then Łódź. ${ }^{29}$ If there are any tangible traces of $\mathrm{K}$. Miaskowski's numismatic activity in the parishes where he worked, they may take various forms. These can be manifested both by an increase in information about the finds that

25 Laszkiewicz 2014: 108; cf. Jarzęcki, Rakoczy 2010: 55, 58 .

26 By the way, the parish in Ostrów near Gniewkowo was under the patronage of the Schlichting family from Wierzbiczany (Łaszkiewicz 2014: 112-113).

27 Banaszak 1983.

28 Sinczuk 2019

29 Wielowiejski 1998: 193. reached scientific institutions, which should be considered to be the case in the finding of coins of Antoninus Pius from Babolin, in the commune of Gniewkowo, ${ }^{30}$ as well as the absence of any such information. Perhaps this is one of the reasons for the lack of recorded finds of coins, and not only ancient, in both the Gniewkowo and Rojewo communes during the years 1909-1939, (excluding the finds from Gąski, ${ }^{31}$ revealed thanks to $\mathrm{Z}$. Zakrzewski). ${ }^{32}$ A significant number of archaeological sites from the first centuries of our era have been identified in the area of these communes, ${ }^{33}$ and yet it was an area which was put to agricultural use all the time during this period, so it is doubtful that no coins had been found. From the perspective of the current state of knowledge about finds of ancient coins from the vicinity of Inowrocław, a concentration of finds of bronze coins north of Inowrocław is evident, especially in the communes of Rojewo and Gniewkowo: Bąbolin, Gąski, Płonkowo, Rojewo, Szadłowice, Szpital, etc. ${ }^{34}$ The archaeological site on which the research

30 The description shows that it is a cremation grave field (,Dicht beim Gehft auf einem Feld gefunden, auf dem fters Urnen zu Tage kommen"). The coins were offered to the Society on 9 March 1909 and sold in July 1909. (Fredrich 1909: 15; Jarzęcki, Rakoczy 2010: 55). This is probably the latest find included in the work of C. Fredrich.

31 Coins have been found in Gąski many times during the post-war period, including in 1987 a hoard of 140 denarii, including issues of Marcus Aurelius, Commodus and Septimius Severus (Cofta-Broniewska 1987 (1988): 115), and as is shown by photographs (Cofta-Broniewska, Kośko 2002: 163), also of Antoninus Pius, Faustina I, Lucius Verus and Faustina II.

32 Por. Kalliefe 1915; 1918; Gumowski 1958; Krzyżanowska 1960: 197-199; Zielonka 1969.

33 A. Cofta-Broniewska tried to reconstruct the course of the amber route in this area, understood as a physically existing road, based on the planigraphy of these sites: 'the route ran along the western edge of the Inowrocław Upland towards the north-east, reaching Płonkowo-Kaczkowo, where it turned eastwards and making two S-shaped bends through Bąbolin, Murzynno, Grabie, Opoki, Służewo, reaching Otłoczyn, that is, to the point of the crossing that was there' (Cofta-Broniewska 1979: 136). I omit a critique of this hypothesis because it has been done many times before, see note 9 .

34 Jarzęcki, Rakoczy 2010: 55-61. This may be due to the cultural situation in the first centuries of our era, the state of research at that time, the activity of coin collectors in the area, or it may be a combination of all these factors. As far as factor of the collectors is concerned, it would have an impact on the the finders of any coins if they were aware that they could find ready buyers for 
has been conducted, and which follows this trend is Perkowo. ${ }^{35}$ So there is a certain probability that the as of Trajan, and the sestertius of Gordianus III, now in the Jan Kasprowicz Museum collection (cat. No. 14, 20), were found somewhere in that area. The fact that Miaskowski's numismatic collection was created, and was mainly is based on finds, is indicated by other coins purchased from this collection for the museum. They include a set of silver coins from the first half of the 17th century with a number of features typical for hoards found in Poland. ${ }^{36}$ It should also be added that among the coins purchased from the collection of K. Miaskowski by the MJK, apart from the ancient ones, only the issues from the times of Sigismund III (1587-1632) were more recent. Considering Miaskowski's interests in the Renaissance period, the absence of other coins from the 16th century is even more strange. As far as one can judge, looking at the coins from the K. Miaskowski collection as a whole (the question remains as to what part of this collection went to Inowrocław), it can be seen that ancient coins were not the main object of the numismatic interests of their owner. Based on the coins that found their way to Inowrocław, it almost gives the impression of a collection created in a quite random manner. The dominance of coins related to Poland, including an issue of the November Uprising of 1831, indicates that it could be to some extent 'patriotic', consisting in collecting (and to protect against melting) souvenirs related to the former Polish state, and attempts to rebuild it. They could also have been attempts to supplement the collection, and systematize it to give it just such a character. It is significant that this set of coins, hypothetically a hoard, was not published. It is difficult to identify specific obstacles to this happening before 1918, except that the owner did not want to disclose the discovery of these coins for fear of robbery. If the coins were discovered after Wielkopolska joined the reborn Poland, in 1919, another real obstacle could be the necessity to pay a high tax $(50 \%)$ on the find. In the context of the collection under discussion, it should be taken into account that due to the approaching German invasion of Poland in 1939,

any coins, not only those made of precious metals. In this context, the lack of information about coins cut in half, and the lack of any such coins in the Jan Kasporowicz Museum, is puzzling.

35 Kurpiewski, Rakoczy 2015: 27.

36 One of the first steps in future research should be to verify that a very similar finds have not already been published as being in a private collection. who soon after forced K. Miaskowski to leave Ostrowo, these coins were probably hidden for several years, and maybe even buried, similarly to other Polish collections ${ }^{37}$, and re-excavated in the years 1945-1947.

The last group of coins to be dscussed in this article (cat. No. 4, 5, 22, 23) was purchased on 28 October 1998 from Stanisław Leszczyński from Inowrocław. The bronze coin of Constans (cat. No. 22 ) is in the best condition, the others, bronze issues of Pantikapaeum, Phanagoria and Valentinian are quite badly damaged. It is even surprising that the museum decided to purchase such damaged, and quite common coins, at an exaggerated price. Maybe there was a serious reason for this purchase that was not noted in the documentation? Thematically, these coins fit well with the group of coins purchased in 1965. Could they be part of the same collection, sold 33 years afterwards, but without the envelopes written by the previous owner?

The oldest coin in the Jan Kasprowicz Museum collection is the bronze dichalkon of Olbia, dated to the first quarter of the 4th century $\mathrm{BC}$ (cat. no. 3). It is one of the most popular coins of this Greek polis. Discussion as to the attribution of the head shown on the obverse is still open, and many arguments can be put forward for each of the interpretations advanced in favour of Demeter or Apollo. The next Olbian coins (cat. No. 1, 2) are very similar in terms of iconography, but have a slightly larger diameter and several times the higher weight. They have the form of truncated cones, not discs. They could have appeared to have been a higher denomination of coin number 3 , and it is possible that they were perceived as such by the previous owner, which kept the coins no. 2 and 3 in the same envelope The explanation most in favour nowadays is that a significant chronological difference separates the issues. It is believed that the latter type were minted around 180-170 BC. These are coins much rarer than the coin no. 3 .

The bronze tetrachalkon from Panticapaeum with a bow in a gorytos hung horizontally on the reverse, and Apollo's head facing right on the obverse (cat. No. 4) is a fairly common coin. The most popular dating proposals are listed in the attached catalogue. It is worth noting that scholars agree in principle that these are emissions from the 2nd century BC and such a view seems correct, if we take into account, inter alia, the presence

37 Gumowski 1966:117-118; Jasek, Woźniak 2019: 23 , etc. 
of a similar representation in the coinage of other northern Black Sea shore centres, e.g. Skilures' coins from Olbia. Due to the great popularity of these coins found in archaeological sites, it is hard to expect a breakthrough. However, another hypothesis can be proposed. Taking into account the similarity of the representation on the reverse to coins of King Spartocus, it should be considered whether they are not contemporary issues. It is doubtful that the very small issue of silver coins bearing the name of Spartocus would be able to meet the demand for coins in the Bosporus. This role had to be played by the coins issued on behalf of the citizens of Panticapaeum, which would be a successful iconographic reference to the royal issue. This still does not resolve the issue of chronology, since it is not known exactly when Spartocus reigned.

The bronze dichalkos of Phanagoria, dating from the end of the 3 rd century BC. (cat. no. 5) is also a very common coin is. In terms of iconography, these coins refer to the very popular type of Panticapaeum coins, with a satyr on the obverse and a bow and arrow and below the legend MAN on the reverse. Although all the coins currently under study are generally the most popular Bosporan coins, the coins of Panticapaeum are carefully made, whilst the issues imitating those of Phanagoria are downright primitive. This is especially evident in the depiction of the head of the satyr. On the other hand, the motif on the reverse is interesting. While the Panticapaeum coins undoubtedly depict a recurrent bow and an arrow motif, on the Phanagoria coins the arrow often resembles a caduceus, and on some specimens it certainly is a caduceus. ${ }^{38}$ This is an iconographic type that can be associated with coins of King Leukon II which show a bow and a club on the obverse. They are contemporary or chronologically very close to the coins of Panticapaeum bearing a bow and arrow. In the case of the coins of Phanagoria, it is not always possible to decide whether it was an intended effect or resulted from the low competence of the die engraver.

Another coin (cat. No. 6) is also an issue of Phanagoria, but from the time when the city was called Agrippia. ${ }^{39}$ The coin is not rare, although there are very few Bosporan examples of the coins

38 https://bosporan-kingdom.com/147-3132/ [access: 23. 06. 2021]

39 In the literature, Agrippia is generally identified with Phanagoria, but there are other hypotheses as well, see Mel'nikov 2015. found in Poland, and the information about them is not always fully reliable. ${ }^{40}$ It is the only known Phanagorian issue under that name ${ }^{41}$. Its 'sister' issue are the coins of Panticapaeum, bearing the name Caesarea. Both types of coins are the latest or one of the most recent issues by cities on the Bosporus. Moreover, no coins are known, neither from the Bosporus nor from any other centre of the Northern Black Sea coast, that can be considered their close analogy. It is generally believed that the date of issue of these coins is chronologically close to the re-naming of the two most important centres on the Bosporus in honour of Octavian Augustus and Marcus Agrippa, which would have taken place at the end of the 1 st century BC. The question remains why the renaming of the city and the issue of these coins are considered to be chronologically close. There are indications that these events were even several dozen years apart. Suppose that the names of the cities were changed after Octavian and Agrippa won the war with Mark Antony ${ }^{42}$.

40 See: Bodzek, Madyda-Legutko 2018; ibid, p. 72 the coin (ie. the 'sestertius') found in Gąski, commune Gniewkowo - in my opinion, judging from the photo, it is an issue of Rheskuporis II (68/69-91/92 AD).

${ }^{41}$ On the metrology of these coins see: Frolova, Ireland, 2002: 50-52; Pl. XXXII-XXXIII.

42 In the history of the Bosporan state, there were at least three such situations: i.e. the struggle of the 'legal' emperor based in Rome, and a ruler proclaimed in the East, with the Bosporus always siding with the latter. The second took place in AD 69 when the Bosporan king Rhescuporis I (68/69 - 91/92) sided with Vespasian against Vitellius. We can infer, inter alia from coins, that the Bosporus benefited greatly from it, and the local kings ostentatiously manifested their friendship with the Empire. The third situation of this kind was the support given by King Sauromates II (174 / 175-210 / 211) to Pescennius Niger against Septimius Severus in 193-194 (Jarzęcki 2016: 23). The 'numismatic' consequence of this event are countermarks with the portrait of Septimius Severus placed on Bosporan coins issued at that time, and even placed on the dies of coins of the same type struck after the defeat of Pescennius. The reason for the support of the Eastern rulers by the Bosporan kings was probably the pressure exerted by both the usurper himself and his allies, and the awareness that if they did not take the side of the usurper, they would become a target of attack themselves. This is the easiest way to explain the mild consequences of the alliance with Mark Antony and Pescennius Niger. However, one cannot forget about the developed contacts of the Bosporus in the East, reaching, inter alia, Egypt (see Olszta-Bloch 2011). It is no coincidence that the portrait of Emperor Hadrian appeared on Bosporan staters within 43 days of his assumption of power (in Syrian Antioch). In terms of iconography, 
The reason for such a decision, which King Asandros (51/50-22/21 BC) could have made, was not his servility to Rome, but an attempt to maintain power and the independence of the Bosporus. It seems very possible that during Augustus' war with Antony, the Bosporan ruler, like "the whole East", supported the latter. In the case of Asandros, whose coins are rich in the symbolism of naval victories, it could have been triggered by his despatch to Antony of a naval contingent. After losing the war, punished only with losses incurred in the fighting (that is, perhaps with everything he sent to the Battle of Actium), he manifested his loyalty to Rome. By the way, he may have previously been an ally of Julius Caesar, because they had a common enemy in King Pharnakes. A very similar case outside the Bosporus is the case of Herod the Great and the re-naming of Caesarea Maritima, although the ruler of the Bosporus did so to the extent of his much smaller financial capacity. As mentioned above, it is often believed that these coins were minted in the period close to the renaming of the city $^{43}$. Giving the name Caesarea was given to the main centre in the state this seems understandable. It is difficult to judge whether Phanagoria was renamed Agrippia due to its rank as the second most important centre in the state. Undoubtedly, however, it was Phanagoria that had traditions that could be most easily intertwined with the symbolism of the battles at sea against Antony, culminating in the victory at Actium in $31 \mathrm{BC}$ (this symbolism was expressed by various means, including the denarii, struck in Rome in $12 \mathrm{BC}$, depicting Agrippa wearing a combination of corona muralis and corona rostrata (RIC I 414)). From Fanagoria come the coins with the head of Poseidon on the obverse, and the prora on the reverse, dating from 109-100 $\mathrm{BC}$, and the coins with the head of Apollo and the prora to the right and the legend ФАNАГО / PITSN. Iconographically the reverse is similar to Asandros coins, which are probably contemporary to them. According to V. A. Anochin, they come from 27-21 BC, according to I. B. Sonov from 43-39 BC, and according to D. MacDonald from 47-16 BC. In my opinion, the most probable is the chronology proposed by Sonov, with the lower

the Bosporan coins in this period were much more similar to coins minted in Asia Minor or Rome, than coins from Thrace, from which the Bosporan ruling dynasty originated, or the province of Lower Moesia, which at one time reached as far as Olbia or the Tauric Chersonesus.

43 Eg. Frolova, Ireland 2002: 49-50; Ashton 2003: 381; RPC I: 335; SNG Stancomb 2000, Pl. XXVIII; SNG Cracow 2006, Pl. XXXIV. boundary being shifted to $31 \mathrm{BC}$. By adopting such a date, it is easy to reconcile the idea that the name of Phanagoria was changed to Agrippia in $31 \mathrm{BC}$ or shortly thereafter, and the issue of coins bearing that name continued until the end of the 1 st century $\mathrm{BC}$, which is accepted by most researchers, in this case, it is to be understood as a period of thirty years ${ }^{44}$. The issue of coins with bearing the new names of the cities would not only be a response to specific economic needs, but, to a large extent, if not primarily, an 'advertisement' of this change. As it turns out, it was a very effective advertisement, because coins are the only source by which these new names are known.

According to another hypothesis, no less probable in my opinion, the coins described come from the time of Queen Gepaepyris (37/38-38/39 $\mathrm{AD})^{45}$. The argument in favour of this hypothesis is the close similarity of the depiction of the female head, probably Aphrodite, on Gepaepyris coinage belonging to the denomination of 12 units, and the head depicted on the coins of Caesarea with the denomination of 8 units. In this case, the historical background of their issue and probably a significant reason, was the rivalry of the queen's son, Mithridates with the Polemon II the king of Thrace, for recognition by Emperor Caligula of their power over the Bosporus. The emperor favoured Polemon as a relative of his grandmother Antonia the Younger, but ultimately the Bosporan throne was granted to Mithridates, and the Pontic throne to Polemon. One of the outstanding issues with these coins is the attribution of the female head depicted on the obverse. Usually it is written that Aphrodite is depicted on both the coins of Caesarea and Agrippia. This can be accepted only for the coins of Caesarea, but rejected for the coins of Agrippia. After all, these are completely different depictions. Already in the 19th century the depiction on the coin of Agrippia was attributed to some mortal woman, Queen Dynamis (as on the description on the envelope) or the Empress Livia. This view has been criticized and rejected by scholars ${ }^{46}$. In my opinion, those scholars who claimed that it was Livia's portrait were right. This is indicated, among other factors, by her distinct hairstyle. Coins with her portrait minted in other various centres also provide an argument in favour

44 According to D. MacDonald (2005: 53, 59), they were struck in the years $14-12$ BC in connection with the intervention of Rome in the Bosporus to support King Polemon I. This is a very probable hypothesis.

45 Anochin 1986: 84-85.

46 RPC, I: 335. 
of this interpretation. Interestingly, scholars are agreed that on the bronze coins of Tiberius dating to AD 21-23 Livia was depicted with the legends IVSTITIA (RIC 46), or SALVS AVGVSTA (RIC 47) or, with a veil, as PIETAS (RIC 43). It seems that this similarity was clear to contemporaries. A striking example are coins from Macedonia, depicting Livia with the legend PIETAS (RPC 1543). The Empress was depicted on the coins of Panormus in Sicily (RPC 642) and Corinth (RPC 1155-1156) in a manner very similar to those of Bosporan Agrippia. Moreover, she was depicted very carefully on coins from Oea in the province of Africa Proconsularis (RIC 835), although without a legend. It should also be added that an inscription is known concerning the erection by Queen Dynamis of a statue for Livia from Phanagoria itself (CIRB 978), who was venerated there on a par with Augustus (cf. CIRB 1046).

The bronze coin of Alexander Severus of Nicea in Bithynia (cat. No. 7) is of a fairly common type. In the light of current knowledge, however, it is the first such discovery in Poland. ${ }^{47}$

The bronze Numidian coin of Masinissa (cat. No. 9) is not only a unique find in Poland, ${ }^{48}$ but also a numismatic curiosity. The ruler's head is directed not to the left as usual, but to the right.

The group of three Roman republican denarii (cat. No. 10-12) is a kind of illustration to the famous fragment of Germania of Tacitus (5), concerning the coins preferred by the Germans. ${ }^{49}$ By the way, both bigati and serrati of the same types as coins No. 11 and 12 appeared in two currently known hoards of Roman Republican coins in Poland: in the hoard from Połaniec ${ }^{50}$ and that from Nowa Wieś Głubczycka. ${ }^{51}$ In Poland, Republican denarii, usually issued by Mark Antony, are most often found as the oldest element in hoards, in which the most recent issues come from the turn of the 2nd and 3rd century AD. An example is a hoard from Drzewicz. ${ }^{52}$ Among the Republican denarii from the Jan Kasprowicz Museum, the serratus (cat. No. 12) is of particular interest. The coin is distinguished by its low weight, $3.33 \mathrm{~g}$ and the presence of a round countermark on the obverse. The average weight of 344 denarii of this

47 Myzygin, Sidarovich 2020.

48 Cf. Kozłowski 2003.

49 „Pecuniam probant veterem et diu notam, serratos bigatosque".

50 Kunisz 1985: 165-171.

51 Dymowski, Rudnicki 2019: 55.

52 Krzyżanowska 1976. type from the portal acsearch.inf ${ }^{53}$ is $3.822 \mathrm{~g}$ with a weight range from 2.56 to $4.44 \mathrm{~g}$. The three lightest coins from acsearch.info $(2.56,2.61$ and 2.67) have a visible iron core, which is also seen in many other coins weighing less than $3.40 \mathrm{~g}$. The lightest denarius, undoubtedly entirely made of silver, with an ' $\mathrm{S}$ ' shaped countermark, weighs $2.85 \mathrm{~g}$. There are only 3 denarii in the weight group 3.31-3.40 g. ${ }^{54}$ Among 351 denarii of this type, out of 14 (which is nearly 4\%) there are 7 different countermarks, with round one being the most popular. Countermarks were placed almost exclusively on the obverse. Possibly, the category of countermarks should also include carvings made with a sharp tool, placed on the obverses of some coins.

The Trajanic denarius (cat. No. 13) was discovered in 2010 during archaeological research at Plac Klasztorny in Inowrocław in a modern grave. Many publications have already been devoted to this find ${ }^{55}$ However, there are several reasons for re-publishing this coin. First, it has been possible to identify it fully, ${ }^{56}$ and thus establish its catalogue analogy as RIC 6 . The die axis of the coin is not $0^{\circ}$, as is shown in previous publications, but $180^{\circ}$. It should also be added that on the reverse of the coin there is a carving resembling the letters M S. From the perspective of coin studies, it is a unique case in Poland that in the modern period (16th-17th century) an ancient coin was converted into a medallion, by drilling a hole in such a way as to expose and not damage the emperor's bust on the obverse, but wipe the reverse. According to the authors of previous studies, the coin prepared in this way was converted into a 'head of Saint John' the Baptist, ${ }^{57}$ that is, the purpose of the procedure was to transform the coin into a medal with the image of the saint. This interpretation and the arguments in favour of it are convincing. It should be emphasized that although the perception of Roman coins as 'Saint John's head' by the population is known from old Polish literature, this coin is the only known artefact that could be treated as a manifestation of these beliefs. Taking into account

53 Access date: 12. 06. 2021.

54 On the weight of Roman denarii cf. Jarzęcki 2019; 2020: 92.

55 Bogucki, Dymowski, Śnieżko 2017: 285; Bogucki, Dymowski, Śnieżko 2020: 386; Siwiak 2017: 178-179; Siwiak 2018: 121-122.

56 I sincerely thank the director of the Jan Kasprowicz Museum, Mr. Marcin Woźniak, for allowing me to take a large series of photos of this coin with different lighting and to view it through a microscope.

57 Por. Mt 14, 11. 
the culture of the times when the coin was transformed into a medal, including the perception of Emperor Trajan, ${ }^{58}$ and analogies from southern Europe $^{59}$ other interpretations of this find could also be proposed: specifically the hypothesis that the woman wearing the medal was aware that the emperor Trajan was depicted on it. ${ }^{60}$

The as of Trajan (cat. No. 14) and the sestertius of Gordian III (cat. No. 20), although they came to Jan Kasprowicz Museum from the same collection, were probably not found together. This is indicated by their completely different state of preservation, and traces of other processes that they have been subjected to since Antiquity.

This article republishes a denarius of Antoninus Pius found in Krusza Zamkowa (cat. No. 15) This is the first time that a full description of this coin has been made, along with a catalogue analogy. It is a variant of the RIC 127 type, as well as metric data and a more precise location within Krusza Zmakowa. In numismatic literature, this type of denarii is dated, based on of information about the emperor's fourth consulate, to the years 145-161. Based on a comparison of the weight parameters of this type of denarii to those of Marcus Aurelius, which can be more precisely dated, it is possible to propose a narrowing of the chronology to the years $145-147 .{ }^{61}$

The same principle can be used to refine the chronology of the posthumous denarius of Faustina I (cat. No. 16), previously dated 141-161, to the years $152-153 .{ }^{62}$ From the same research emerges a very logical rule that the posthumous denarii of Faustina I, bearing the legend AVGVSTA on the reverse, are contemporary to the denarii of her living daughter, Faustina II, with the reverses composed according to the same principle. A characteristic feature of the specimen described is the trace of a file on the bust of the empress. It is possible that in this way the finder, or one of the previous owners, checked what metal the coin was made of.

The denarius of Marcus Aurelius dating to 165-166 (cat. No. 17) is quite a rare coin. The RIC 148 type, with the same reverse, but with the legend M ANTONINVS AVG ARMENIACVS on the obverse is much more popular. The specimen from the Jan Kasprowicz Museum collection is in good condition.

The denarius of Lucius Verus (cat. No. 18) is

58 Cf. Dante, Paradiso, XX, 43-48.

59 Np. Fiò 2012: 34.

60 This will be the subject of a separate study.

61 Jarzęcki 2019: 157, 165.

62 Jarzęcki 2019: 166, 175. of a fairly low weight. The average for this type of RIC (including busts with and without armour) is $3.18 \mathrm{~g}$ (15 copies) with a weight range from 2.91 to 3.61 g. ${ }^{63}$ It is possible that some denarii of Lucius Verus from 165-166 and 166-167 were struck outside the mint at Rome. This hypothesis should be tested in cases of this type of denarii, among others, which do not have their 'counterparts' in terms of iconography in Marcus Aurelius' coinage. ${ }^{64}$

The denarius of Marcus Aurelius type RIC 377 (cat. No. 19) is a coin that, despite severe abrasion, weighs $3.04 \mathrm{~g}$. The average weight of this type is $3.193 \mathrm{~g}$ (16 copies) with a weight range from 2.46 to $3.58 \mathrm{~g} .{ }^{65}$ As we can see, the original weight of this specimen was significantly above the average.

The sestertius of Gordianus III of type RIC 298a (cat. No. 20) is a one-off issue, dating to 241243, which also includes ases, dupondii (RIC 298), antoniniani (RIC 84) and aurei (RIC 99) The series with Jupiter and the legend of IOVIS STATOR is chronologically similar. This type is not one of the most popular sestertii of Gordianus III. In Poland, the finds of Gordianus sestertii are generally very rare. Type 298a is known from Zabrze (Silesian Voivodeship), ${ }^{66}$ and other types, from Rzepiennik Strzyżewski (Lesser Poland Voivodeship) a sestertius RIC 297, ${ }^{67}$ from Kutno (Łódź Voivodeship) a sestertius RIC 281, ${ }^{68}$ from Warsaw (Jelonki) a sestertius RIC 254, ${ }^{69}$ and from Chorula (Opole Voivoideship) a sestertius RIC $297 .{ }^{70}$ Silver coins are much more popular from this period, ${ }^{71}$ and M. Levy had in his collection a silver coin of Gordianus III from the vicinity of Inowrocław. ${ }^{72}$

Coins of Galerius are rare in Poland. The coin from the Jan Kasprowicz Museum, RIC 48b (cat. no. 21) is quite rare. There are only 3 coins of this type on acsearch.info ${ }^{73}$ including one with the letter A between the figures on the reverse.

The bronze of Constans type RIC 183 (cat. No. 22 ) is a rare coin. There are 3 coins of this type on acsearch.info. ${ }^{74}$ The closest reliable find of a bronze coin of Constans to the example from Inowrockaw

63 acsearch.info [access: 15. 06. 2021]

64 Jarzęcki 2015: 48.

65 acsearch.info [access: 14. 06. 2021]

66 Ciołek 2008: 304.

67 Kunisz 1985:194.

68 Kubiak 1979: 55.

69 Kubiak 1979: 74.

70 Ciołek 2008: 47

71 Dymowski 2011: 78.

2 Jarzęcki, Rakoczy 2010: 57.

73 Accessed 21.06. 2021.

4 Accessed 21. 06. 2021. 
comes from Toruń. ${ }^{75}$ In addition a gold medallion, struck in Aquileia and weighing 9 solidi $(41 \mathrm{~g})$ was found in Opoczki (commune of Aleksandrów Kujawski). ${ }^{76}$

The bronze coin of Valentinian I (cat. No. 23) is quite rare. There are 36 copies on acsearch.info, including 33 with the weight given, from various officinae of the mint of Siscia. ${ }^{77} 6$ coins come from the $1^{\text {st }}$ officina, 5 from the $2^{\text {nd }}$, and 25 from the $3^{\text {rd }}$. The specimen from the Jan Kasprowicz Museum, struck in the $2^{\text {nd }}$ officina, is not one of the most common types. The average weight of the 32 fully preserved specimens is $2.559 \mathrm{~g}$ with a range from 2.04 to $3.20 \mathrm{~g}$. The low weight of the our coin $(1.80 \mathrm{~g})$ results from corrosion loss, and probably quite low original weight.

Coins of Valentinian I are very rare in Poland, ${ }^{78}$ although one find was made in Brześć Kujawski in $1850,{ }^{79}$ and another in Torun. ${ }^{80}$ In the case of the coin from Brześć, there is no more precise information other than the name of the issuer. The coins found in Torun are issues of various types from Siscia and Sirmium. Coins no. 21 and 22 could have been found in Poland, although it is more likely that they were brought from abroad, possibly as holiday souvenirs (?). Coin No. 22 is corroded and has had the patina chemically removed. Coin no. 21 has a noble, natural black patina. It is possible that both were surface finds.

\section{Catalogue $e^{81}$}

Greek coins
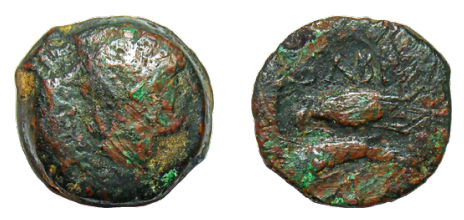

75 Olszta-Bloch 2004: 55.

76 Jarzęcki, Rakoczy 2010: 58.

77 Accessed 21. 06. 2021.

78 Kunisz 1985: 289.

79 Kubiak 2979: 26.

80 Olszta-Bloch 2004: 54-55.

81 In addition to the coins described in this article, the collection of Jan Kasprowicz Museum in Inowrocław contains five Roman coins, found using metal detectors in Perkowo, commune of Gniewkowo, which were accompanied by other artefacts, and whose findspot is known in detail. These finds are yet to be published, and they will be the subject of a separate study in the future. The finds from Perkowo include: (1) Faustina II, denarius, RIC 677; (2) Trajan, denarius, RIC 121; (3) Trajan, denarius, RIC 355; (4) Commodus, denarius, RIC 249; (5) Trebonianus Gallus, antoninianus, RIC 30.
1. Olbia, obol, 180-170 BC (Fig. 5)

obv: head of Demeter or Apollo r.

rev: eagle flying 1., clutching a dolphin in its talons, $\mathrm{O} \Lambda \mathrm{BIO}$

AE, 8,67 g, 19,5-20,3 mm, $7 \mathrm{~h}$; Anochin 2011, 480 (?); SNG Cracow 156-161, no. inv. 1169

provenance: purchased 22. 06.1965

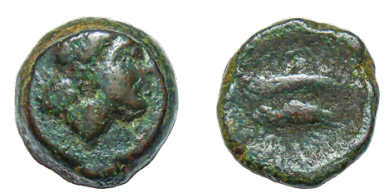

2. Olbia, obol, 180-170 BC (Fig. 6) obv: head of Demeter or Apollo r. rev: eagle flying $r$., clutching a dolphin in its talons

AE, 9,21 g, 16,6-17,2 mm, 10 h; Anochin 2011, 481 (?), SNG Cracow 156-161, no. inv. 1170

provenance: purchased 22.06. 1965

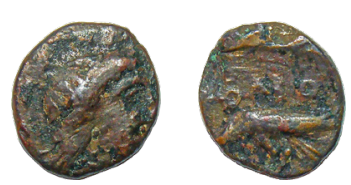

3. Olbia, dichalkon, $1^{\text {st }}$ quarter of IV century BC (Fig. 7)

obv: head of Demeter or Apollo r.

rev: eagle flying 1., clutching a dolphin in its talons, $\mathrm{O} \Lambda \mathrm{BIO}$

AE, 2,74 g, 14,4-16,1 mm, 5 h, Karyškovskij 1988: 54; no. inv. 1171

provenance: purchased 22. 06.1965

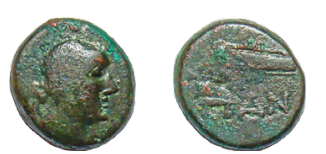

4. Pantikapaion, tetrachalkon, 150-140 BC (wg Anochin 1986, 169), 200-150 BC (MacDonald 139), time of Spartokos (?) (Fig. 8)

obv: head of Apollo $\mathrm{r}$.

rev: bow in case, ПАН

AE, 2,88 g, 12,1-13,45 mm, 9 h, Sonov 258, Anochin 169, no. inv. MKI-N-2265

provenance: purchased 28. 10. 1998 from Stanisław Leszczyński, Inowrocław 


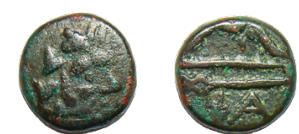

5. Phanagoria, dichalkon, late III century $\mathrm{BC}$ (Fig. 9)

obv: wreathed and bearded head of satyr $\mathrm{r}$.

rev: bow over arrow to r., below $\Phi A$

AE, 2,25 g, 12,0-12,35 mm, 5 h, Anochin 147;

SNG Stancomb 622; no. inv. MKI-N-2264

provenance: purchased 28. 10. 1998 from Stanisław Leszczyński, Inowrocław
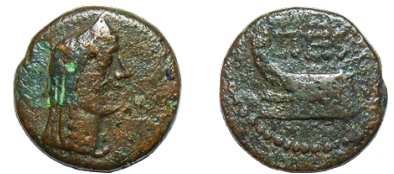

6. Agrippia (Phanagoria), 8 Units, late I century BC or 37/38-38/39 AD (Fig. 10)

obv: veiled and diademed head of Livia r., rev: prov 1., above [АГРІП] / ПЕ $\Omega[\mathrm{N}]$, to r. [H], dotted border

AE, 3,77 g, 16,85-17,1 mm, 12 h, RPC I 1935, SNG Stancomb 631; [SNG Cracow 439-441]; no. inv. 1172

provenance: purchased 22.06. 1965
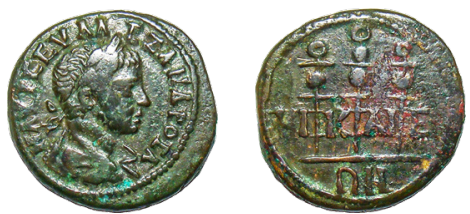

7. Nicaea (Bithynia), Severus Alexander, 222-235 $\mathrm{AD}$ (Fig. 11)

obv: laureate and draped bust of Severus Alexander r., M AYP CEY A $\Lambda E \Xi A N \triangle P O C$ A, dotted border

rev: three military standards, each topped with wreath, NIKAIE / $\Omega \mathrm{N}$, dotted border

AE, 4,52 g, 1 h, 20,2-21,35 mm, SNG Cop. 520 provenance: according to the donor found in Piłakno Lake (Mrągowo County, Commune Sorkwity) at the depth of 8 meters

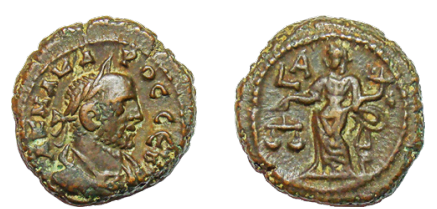

8. Alexandria (Egypt), Carus, tetradrachm, RY 1 $=282 / 283$ AD (Fig. 12)

obv: laureate and draped bust of Carus r., A K M A KAPOC CEB, dotted border

rev: Dikaiosyne standing facing, head 1., holding scales in $\mathrm{r}$. hand and cornucopia in 1., L A, dotted border

BI, 7,78 g, 18,3-19,4 mm, 1 h, Emmett 3996, no. inv. 1173

provenance: purchased 22.06. 1965

Numidian coins
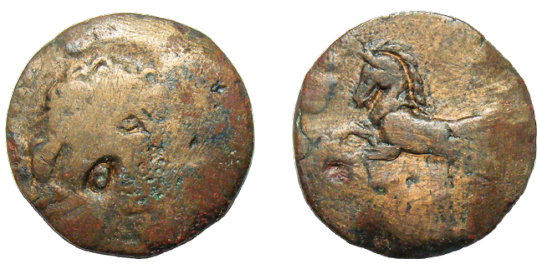

9. Masinissa (205-148 BC) (Fig. 13)

obv: head of Masinissa 1., dotted border rev: horse galloping 1 .

AE, 14,21 g, 24,8-25,25 mm, 2 h, no inv. MKI$-\mathrm{N}-2007$

provenance: donated 11. 09. 1989 by Marian Walczak, Inowrocław

bibliography: Kozłowski $2003^{82}$

Roman coins
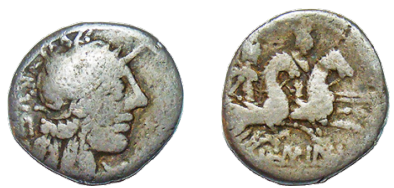

10. Q. Minucius Rufus, denarius, 122 BC (Fig. 14) obv: helmeted head of Roma r., behind RVF, below chin denomination mark $\mathrm{X}$

rev: Dioscuri riding r., below [Q] MIN[V], in exergue [ROMA]

AR, 3,34 g, 16,4-17,95 mm, $3 \mathrm{~h}$, Crawford 277/1, no. inv. 1167

provenance: purchased 22.06. 1965

8214,19 g, 24,7 mm, Mazard (1955), no. 21 (Kozłowski 2003: 29). 

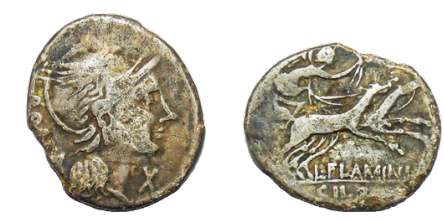

11. L. Flaminius Chilo, denarius, 109-108 BC (Fig. 15)

av: helmeted head of Roma r., behind ROMA, below chin denomination mark $\mathrm{X}$

obv: Victoria holding wreath and reins, driving galloping biga r., below L FLAMINI, in exergue CILO

AR, 3,32 g, 16,8-20,1 mm, $3 \mathrm{~h}$, Crawford $302 / 1$, no. inv. 1402

provenance: purchased 12.08. 1967 from the collection of K. Miaskowski
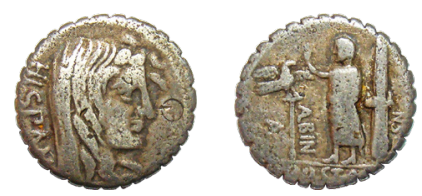

12. A. Postumius Albinus, serrate denarius, 81 BC (Fig. 16)

av: veiled head of Hispania r., behind HISPAN, circular countermark

obv: togate figure standing $r$. with $r$. hand raised between legionary eagle and fasces with axe around, A ABIN A S, in exergue POST A F

AR, 3,33 g, 17,85-18,5 mm, 2 h, Crawford $372 / 2$, no. inv. 1176

provenance purchased 22.06. 1965
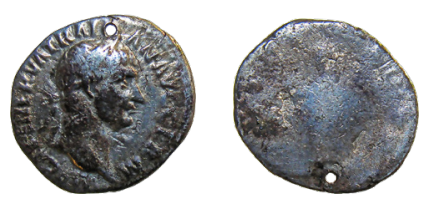

13. Trajan, denarius, 98-99, mint Rome (Fig. 17) av: laureate bust of Trajan r., IMP CAES NERVA TRAIAN AVG GERM

obv: outline of a figure standing left (Pax?), in the left hand cornucopia, in the right stretched out in front an unrecognized object pointing up (an olive branch?), P [M] T R [P] C O S I I P P, dotted border

AR, 2,44 g, 17,2-18,8 mm, $6 \mathrm{~h}$, hole diameter $1 \mathrm{~mm}$, on the right side of the figure on the reverse, at the thigh level, an engraving resembling the letters 'M S', RIC 6, no inv. MKI-A219/I.19-10/10 bibliography: Bogucki, Dymowski, Śnieżko 2017: 285; Bogucki, Dymowski, Śnieżko 2020: 386; Siwiak 2017: 178-179; Siwiak 2018: 121122
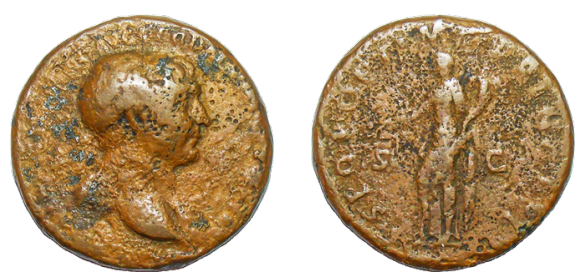

14. Trajan, as, 103-111, mint Rome (Fig. 18) av: laureate and draped bust of Trajan r., [IMP CAES TRAIANO] AVG GER DAC [P M TR P COS V P P]

obv: Aequitas standing facing, head 1., holding scales in r. hand and cornucopia in 1., SPQR OPTIMO PRINCIPI, $\mathrm{S}-\mathrm{C}$ across field

AE, 25,95-26,75 mm,12,14 g, 6 h, RIC 497, no inv. 1306

provenance: purchased 12. 06. 1967 from the collection of K. Miaskowski
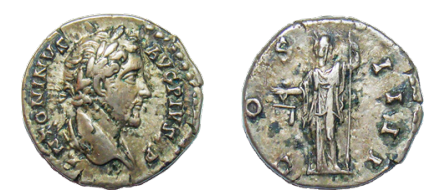

15. Antoninus Pius, denarius, 145-161 (according to RIC), 145(-147?) (according to Jarzęcki 2019: 157, 165), mint Rome (Fig. 19)

av: laureate and draped bust of Antoninus Pius r., ANTONINVS AVG PIVS PP, dotted border obv: Aequitas standing 1., holding scales in $\mathrm{r}$. hand and sceptre in 1., COS IIII, dotted border AR, 3,08 g, 17,85-18,5 mm, 6 h, RIC 127var., no inv. 1097

bibliography: Cofta-Broniewska 1979, no. 849; Cofta-Broniewska, Kośko 2002: 163.

provenance: found accidentally in 1962 in Krusza Zamkowa during agricultural works on small hill in the property of Julian Pater, $3 \mathrm{~m}$ from the border of Józef Kowalczyk's property, near the Noteć river; 'a gift from the finder Julian Pater, who also found a spindle and a fragment of a clay vessel near the findspot' $6.07 .1962 \mathrm{r}$. 


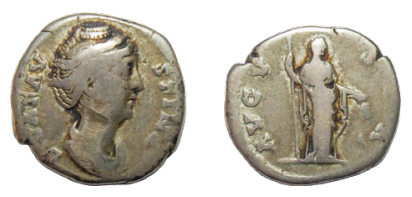

16. Faustina I, denarius, 141-161 (RIC), 152-153 (?) (Jarzęcki 2019: 166, 175), mint Rome (Fig. 20)

av: draped bust of Faustina r., DIVA FAVSTINA, dotted border

obv: Ceres veiled, standing facing, head r., holding grain ears in $\mathrm{r}$. hand and long sceptre in 1., AVGVSTA, dotted border

AR, 3,11 g, 16,65-17,9 mm, 6 h, RIC 358, no inv. 1168

provenance: purchased 22. 06. 1965
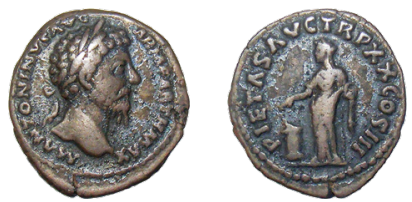

17. Marcus Aurelius, denarius, $165-166$ AD, mint Rome (Fig. 21)

av: laureate bust of Marcus Aurelius r., M ANTONINVS AVG ARM PARTH MAX, dotted border

obv: Pietas standing 1., sacrificing over altar, PIETAS AVG TR P XX COS III, dotted border

AR, 3,13, 18,15-19,3 mm, 12 h, RIC 149, no inv. 1401

provenance: purchased 12. 08. 1967 from the collection of Kazimierz Miaskowski

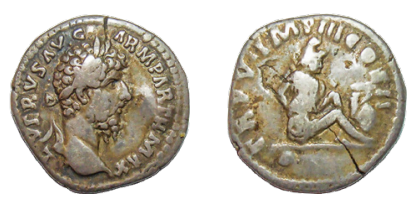

18. Lucius Verus, denarius, 165-166 AD, mint Rome (?) (Fig. 22)

av: laureate bust of Lucius Verus r., L VERVS AVG ARM PARTH MAX, dotted border obv: Parthia ${ }^{83}$ draped, seated r. on ground, his

83 The depiction is sometimes described as a Parthian captive, but the type of depiction in Roman coinage always refers to an allegory. An example is Dacia on denarii of Trajan (RIC 219), which has clearly depicted breasts. The denarii of Lucius Verus, analyzed in isolation from other coins, do not allow for drawing such conclusions. This may be due to the individual style (her) hands tied behind back, in front bow, quiver and shield, TR P VI IMP III COS II, dotted border

AR, 2,83 g, 17,4-18,3 mm, 7 h, RIC 548, no inv. 1175

provenance: purchased 22.06. 1965
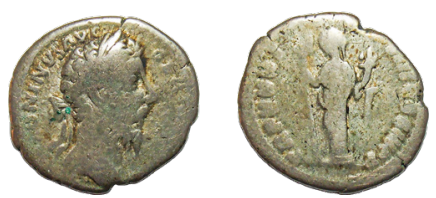

19. Marcus Aurelius, denarius, 176-177 AD, mint Rome (Fig. 23)

av: laureate bust of Marcus Aurelius r., [M ANTO]NINVS AVG [GERM SARM], dotted border

obv: Felicitas standing 1., holding long caduceus in r. hand and cornucopia in 1., TR P XXXI IMP VIII COS III P P, dotted border

AR, 3,04 g, 17,1-19,4 mm, 6 h, RIC 377, no inv. 1177

provenance: purchased 22.06. 1965
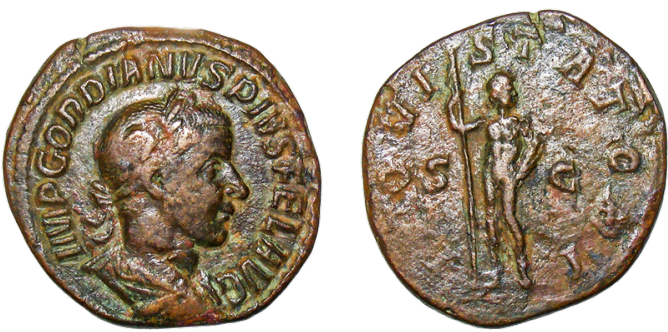

20. Gordianus III (238-244), sestertius, mint Rome (Fig. 24)

av: laureate, draped and cuirassed bust of Gordianus r., IMP GORDIANVS PIVS FEL AVG, dotted border

obv: Jupiter standing facing, head r., holding sceptre in r. hand and thunderbolt in 1., IOVI STATORI, $\mathrm{S}-\mathrm{C}$ across field, dotted border

AE, 18,54 g, 29,7-32,6 mm, 1 h, RIC 298a, no. inv. 1379

provenance: purchased 12. 08. 1967 from the collection of Kazimierz Miaskowski

of the artist making the dies of the coins, cf. the aureus depicting the winged Victoria, RIC 525. 

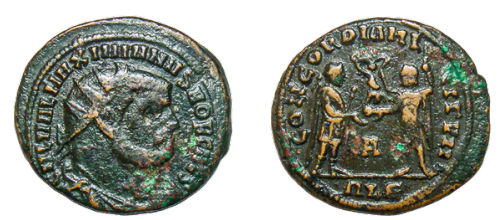

21. Galerius as Caesar, 296-297 AD, mint Alexandria (Fig. 25)

av: radiate and draped bust of Galerius r., GAL VAL MAXIMIANVS NOB CAES, dotted border

obv: Galerius standing r. receiving Victory on globe from Jupiter standing 1., between them A, CONCORDIA MILITVM, in exergue ALE, dotted border

AE, 3,20 g, 20,1-22,3 mm, 6 h, RIC 48b, no inv. 1174

provenance: purchased 22.06. 1965
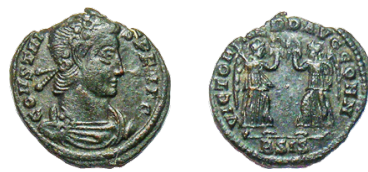

22. Constans I, 340-348, mint Siscia (Fig. 26)

obv: diademed, draped and cuirassed bust of Constans r., CONSTANS PF AVG, dotted border

rev: two Victories standing facing one another, each holding wreath and palm, VICTIRIAE DD AVGG Q NN, in exergue BSIS, dotted border

AE, 1,24 g, 15,0-16,4 mm, 12 h, RIC 183, no. inv. MKI-N-2267

provenance: purchased 28. 10. 1998 from Stanisław Leszczyński, Inowrocław
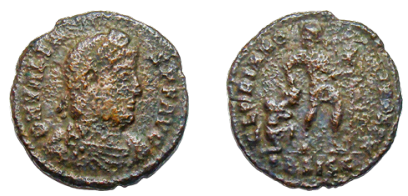

23. Valentinian I, 364-375, mint Siscia (Fig. 27)

obv: diademed, draped and cuirassed bust of Valentinian r., DN VALENTINIANVS PF AVG, dotted border

rev: Valentinian advancing r., head 1., with his $r$. hand dragging captive and with his left holding labarum with Christogram on banner, GLORIA ROMANORVM, in exergue BSISC

AE, 1,80 g, 18,0-18,3 mm, 1 h, RIC 5a, no. inv. MKI-N-2266

provenance: purchased 28. 10. 1998 from Stanisław Leszczyński, Inowrocław
Bibliography

Abbreviations

RIC

RPC I

SNG Cop.

SNG Cracow

Written sources

Dante Allighieri, Divine Comedy.

The Gospel according to St. Matthew.

Tacitus, Germania.

Studies

Anochin V. A. 1986. Monetnoe delo Bospora, Kiev.

Ashton R. H. J. 2003. Excavation Coins from Phanagoreia, The Numismatic Chronicle, 163, 379-385

Babelon E. 1885. Description des monnaies de la République romaine vulgairement appelées monnaies consulaires, Paris-Londres.

Banaszak M. 1983. Miaskowski Kazimierz (18751947) [w:] Słownik polskich teologów katolickich 1918-1981, red. L. Grzebień, t. 6, Warszawa, 452-454.

Baranowski T., Wielowiejski J. 1981. Ziemia kujawska u schyłku starożytności, Ziemia Kujawska, VI, 159-171.

Bodzek J., Jellonek S., Zając B. 2019. Roman provincial coins found in Lessser Poland: an overview, Acta Archaeologica Lodziensia, 65, 51-82. 
Bodzek J., Madyda-Legutko R. 2018. Coins of the Rulers of Cimmerian Bosporus Found in Poland, Note Numismaticae, XIII, 53-89

Bogucki M., Dymowski A., Śnieżko G. 2017. The common people and material relics of Antiquity: The afterlife of ancient coins in the territory of present-day Poland in the Medieval and Modern periods, Studies in Ancient Art and Civilization, 21, 275-297.

Bogucki M., Dymowski A., Śnieżko G. 2020. Catalogue of finds of ancient coins in contexts of the medieval and modern period [w:] Slivers of Antiquity. The Use of Ancient Coins in Central, Eastern and Northern Europe in the Medieval and Modern Periods, M. Bogucki, A. Dymowski, G. Śnieżko (eds.), Warszawa, 367-442.

Bursche A. 1996. Later Roman-Barbarian Contacts in Central Europe. Numismatic Evidence, Studien zu Fundmzen der Antike, 11, Berlin.

Ciołek R. 2008. Die Fundmünzen der römischen Zeit in Polen. Schlesien, Wetteren.

Cofta-Broniewska A. 1978. Inowrocław i jego rejon w pradziejach [w:] Dzieje Inowrocławia, t. I, red. M. Biskup, Warszawa - Poznań - Toruń.

Cofta-Broniewska A. 1979. Grupa kruszańska kultury przeworskiej. Ze studiów nad rozwojem regionalizmu społeczeństw Kujaw, Poznań.

Cofta-Broniewska A. 1987 (1988). Gąski, gm. Gniewkowo, woj. bydgoskie. Stanowisko 18, Inoformator Archeologiczny: badania 21, 114-115.

Cofta-Broniewska A., Bednarczyk J. 1998. Miejsce obrzędowe z doby neolitu i schyłku starożytności w Inowrocławiu, st. 58, Poznań.

Cofta-Broniewska A., Kośko A. 2002. Kujawy w pradziejach i starożytności, Inowrocław-Poznań.

Cohen H. 1859-1868. Description historique des Monnaies frappées sous l'Empire romain, communément appeéles médailles impériales, vol. I - VIII, Paris.

Crawford M. 1975. Roman Republican Coinage, Cambridge.

Dymowski A. 2017. A Small Hoard of Roman Denarii Found in the Region of Kuyavia. The Provenance of Imitative Coins of Roman Imperial Denarii Found in the Territory of Poland, Notae Numismaticae, XII, 111-122.

Dymowski A., Rudnicki M. 2012. Kujawskie znaleziska monet antycznych nowe źródła do dziejów pieniądza na ziemiach polskich, Biuletyn Numizmatyczny, 4 (368), 241-258.
Dymowski A., Rudnicki M. 2019. The Nowa Wieś Glubczycka Hoard and the Influx of Roman Republican Denarii North of the Carpatians [w:] Auf den Spuren der Barbaren - Archäologisch, Historisch, Numismatisch (Archäologie der Barbaren 2015), Hrsg. M. Karwowski et al., Brno, 51-64.

Emmett K. 2001. Alexandrian Coins, Lodi: Clio's Cabinet.

Fiò V. 2012. Il fenomeno della moneta in tomba di epoca medievale nell'Italia nord-occidentale: significati, continuità e rinnovamento di un rito, Tesi di Laurea, rel. prof. T. M. Lucchelli, Venezia.

Fredrich C. 1909. Funde antiker Münzen in der Provinz Posen, Posen.

Frolova N., Ireland S. 2002 The Coinage of the Bosporan Kingdom: From the First Century $\mathrm{BC}$ to the Middle of the First Century AD, BAR Publishing.

Garbaczewski W. 2012. Co miał w sakiewce Michael Levy? Przyczynek do "obiegu" XIX-wiecznych znalezisk monetarnych [w:] Pieniądz i systemy monetarne - wspólne dziedzictwo Europy, red. K. Filipow, Augustów-Warszawa, 250-254.

Gumowski M. 1958. Moneta rzymska w Polsce, Przegląd Archeologiczny, X, 1954-1956, 87149.

Gumowski M. 1966. Wspomnienia numizmatyka, Kraków.

Jarzęcki K. 2015. Lucylla w świetle źródeł numizmatycznych [w:] Pieniądz a propaganda: wspólne dziedzictwo Europy, red. K. Filipow, Augustów-Warszawa, 34-52.

Jarzęcki K. 2016. Mennica w Rzymie w czasach Kommodusa, który zasłynął ze swego szaleństwa, Warszawski Pamiętnik Numizmatyczny, 5, 9-34.

Jarzęcki K. 2019. Struktura wagowa denarów rzymskich z lat 138 - 161, Acta Archaeologica Lodziensia, 65, 157-184.

Jarzęcki K. 2020. Les pièces de monnaies de l'empereur Nerva provenant de la collection du Musée archéologique et ethnographique de Łódź, Acta Archaeologica Lodziensia, 66, 8593.

Jarzęcki K., Rakoczy J. 2010. Wartość źródłowa znalezisk monet antycznych z okolic Inowrocławia, Bydgoszcz - Torun.

Jasek D. F., Woźniak M. 2019. Wspomnienie o Tadeuszu Kałkowskim w 40. rocznicę śmierci, Numizmatyk Krakowski, 1 (385), 1-56.

Kalliefe H. 1915. Neue Funde aus Kujawien, Praehistorische Zeitung, 7, 200-207. 
Kalliefe H. 1918. Kujawische Funde, Praehistorische Zeitung, 10, 169-175.

Karyškovskij P. O. 1988. Monety Ol’vii, Kiev.

Kozłowski J. 2003. Moneta numidyjska znaleziona w Inowrocławiu, pow. loco, woj. kujawsko-pomorskie, Prace i materiały Muzeum Archeologicznego i Etnograficznego w Łodzi: seria numizmatyczna i konserwatorska, 12, 29-35.

Krzyżanowska A. 1960. Skarb denarów rzymskich z Golubia nad Drwęcą, Wiadomości Numizmatyczne, IV, 3, 129-207.

Krzyżanowska A. 1976. Skarb denarów rzymskich z Drzewicza, Wrocław-Warszawa-Kraków-Gdańsk.

Kubiak S. 1979. Znaleziska monet rzymskich z Mazowsza i Podlasia, Wrocław.

Kunisz A. 1985. Znaleziska monet rzymskich z Małopolski, Wrocław-Warszawa-Kraków-Gdańsk.

Kurpiewski A., Rakoczy J. 2015. Materiały kultury przeworskiej z Perkowa na Kujawach, Toruń.

Lubomirski 1873. Zabytki krajowe z okresu bronzowego. Wykopalisko we wsi Raszewie, Wiadomości Archeologiczne, I, Warszawa, 19-36.

Łaszkiewicz T. 1997. Żydzi w Inowrocławiu w okresie międzywojennym 1919-1939, Inowrocław.

Łaszkiewicz T. 2010. Bł. ks. Władysław Demski (1884-1940) - szkic biograficzny, Inowrocław.

Łaszkiewicz T. 2014. Schlichtingowie w Wierzbiczanach - przykład tożsamości regionalnej ziemiaństwa niemieckiego na Kujawach [w:] Pamięć - tradycja - trwanie. Szkice z dziejów Gniewkowa i okolic, red. T. Łaszkiewicz, Gniewkowo, 107-119.

MacDonald D. 2005. An Introduction to the History and Coinage of the Kingdom of the Bosporus, Classical Numismatic Studies, 5, Lancaster - London.

Mielczarek M. 1989. Ancient Greek Coins Found in Central, Eastern and Northern Europe, Ossolineum.

Mielczarek M. 2015. On Bosporan Coins found in Volhynia. The History of the Doubtful Hoard, Bosporskie issledovaniya, 31, 309-314.

Mielczarek M. 2021. For Polish museums... A unique coin collection formed in the Middle East during World War II, deposited in the Archaeological and Ethnographical Museum in Łódź, Łódź.

Mel'nikov O. N. 2015. Kesariâ i Agrippiâ na Bospore. Lokalizaciâ po dannym numizmatiki i èpigrafiki, Tavričeskie studii. Istoričeskie nauki, 7, 79-85.
Myzygin K., Sidarovich V. 2020. Znaleziska prowincjonalnych monet miast Bitynii na ternie Białorusi, Wiadomości Numizmatyczne, LXIV, 208, 187-212.

Olszta-Bloch M. 2004. Zespół późnoantycznych monet brązowych z Muzeum Okręgowego w Toruniu, Prace i Materiały Muzeum Archeologicznego I Etnograficznego w Łodzi: Seria numizmatyczna i konserwatorska, 12, 53-60.

Olszta-Bloch M. 2011. Ptolemejski Egipt i greckie centra północnego wybrzeża Morza Czarnego, Torun.

Politowski P. 2015. Losy prof. Zygmunta Wyskoty-Zakrzewskiego w czasie II wojny światowej w świetle jego korespondencji [w:] Z dziejów pogranicza kujawsko-wielkopolskiego, red. D. Karczewski, M. Wilczek-Karczewska, III, Strzelno-Kruszwica, 121-136.

Rudnicki M., Dymowski A. 2015. Niekończąca się historia - znaleziska monet antycznych z Kujaw, Biuletyn Numizmatyczny, 4 (380), 241270.

Sinczuk I. 2019. Utracony zespół rzymskich monet cesarskich z Muzeum Poleskiego Polskiego Towarzystwa Krajoznawczego w Pińsku [w:] Utracone kolekcje numizmatyczne. Materiały z konferencji naukowej Warszawa 6-7 grudnia 2018, red. J. Piniński, K. Jarzęcki, Warszawa, 237-254.

Siwiak W. 2017. Groby z darami monetarnymi z XV-XVII w. z przykościelnego cmentarza kościoła Marii Panny bydgoskich karmelitów, [w:] Pieniądz i banki na Pomorzu, eds. W. Garbaczewski, R. Macyra, Studia nad dziejami pieniądza i bankowości w Polsce, 3, Poznań,169-190.

Siwiak W. 2018. O denarach rzymskich nazywanych „pieniążkami świętego Jana”, Wiadomości Numizmatyczne, R. LXII, z. 1-2 (205206), 115-128.

Stawicki M. 2015. Szlak bursztynowy i Askaukalis na terenie dzisiejszego Inowrocławia - próba odmitologizowania miejskiej legendy, Ziemia Kujawska, XXIV, 115-122.

Walczak E. 2017. Sylloge Nummorum Graecorum Poland, vol. II, The National Museum in Warsaw, part 2, The Northern Black Sea Coast Bosporan Rulers - Sarmatia, Kraków - Warszawa.

Walczak E. 2018. Sylloge Nummorum Graecorum Poland, vol. II, The National Museum in Warsaw, part 3, The Northern Black Sea Coast Bosporan Rulers - Sarmatia, Kraków - Warszawa. 
Wielowiejski P. 1998. Monety rzymskie z kolekcji Przypkowskich z Jędrzejowa [w:] Nowe znaleziska importów rzymskich z ziem Polski I, Korpus Znalezisk Rzymskich z Europejskiego Barbaricum - Polska, red. J. Kolendo et al., Warszawa, 193-200.

Woźniak M. 2012. Zbiory Muzeum Regionalnego Kujaw Zachodnich w Inowrocławiu (19311938), Rocznik Kasprowiczowski, XII-XIII, Inowrocław, 237-254.

Zakrzewski Z. 1938. Pierwsza moneta na ziemiach polskich, Slavia Occidentalis, 17, 58-104.
Zielonka B. 1969. Rejon Gopła w okresie późnolateńskim i rzymskim, Fontes Archaeologici Posnaniensis, 20, 147-218.

Krzysztof Jarzęcki ORCID 0000-0002-4137-9729

The Leon Wyczótkowski District Museum in Bydgoszcz krzysztof.jarzecki@gmail.com 